Vietnam Academy of Science and Technology
Vietnam Journal of Earth Sciences
http://www.vjs.ac.vn/index.php/jse

\title{
Magma source feature and eruption age of volcanic rocks in the Tram Tau district, Tu Le Basin
}

Nguyen Hoang1*, Tran Thi Huong ${ }^{1}$, Dao Thai Bac ${ }^{2}$, Nguyen Van $\mathrm{Vu}^{2}$, Nguyen Thi Thu ${ }^{1}$, $\mathrm{Cu}$ Sy Thang ${ }^{1}$, Pham Thanh Dang ${ }^{1}$

${ }^{1}$ Institute of Geological Sciences, Vietnam Academy of Science and Technology

${ }^{2}$ Center of Information and Archives of Geology, General Department of Geology and Minerals of Vietnam

Received 19 September 2015. Accepted 13 May 2016

\begin{abstract}
A set of samples including porphyritic rhyolite, rhyo-trachyte, trachyte and basalt was collected in the Tram Tau district, Tu Le Mesozoic Basin, in NW Viet Nam for analysis for major, trace, elemental and Rb-Sr and Sm-Nd isotopic compositions. The volcanic rocks are alkaline and highly enriched in trace elements including rare earth elements (REEs). However, primitive mantle and chondrite trace element normalized patterns expose strong negative anomalies for $\mathrm{Ba}, \mathrm{Sr}, \mathrm{Eu}$ and $\mathrm{Ti}$, possibly reflecting fractional crystallization of plagioclase (for $\mathrm{Sr}$ and $\mathrm{Eu}$ ), pyroxene, and especially amphibole (for $\mathrm{Ba}$ and $\mathrm{Ti}$ ). The measured ${ }^{87} \mathrm{Sr} /{ }^{86} \mathrm{Sr}$ isotopic ratios, varying between 0.8142 and 0.75283 , are plotted against the corresponding ${ }^{87} \mathrm{Rb} /{ }^{86} \mathrm{Sr}$ forming an isochron that provides an age of $157 \pm 2.9 \mathrm{Ma}$ with an initial ${ }^{87} \mathrm{Sr} /{ }^{86} \mathrm{Sr}$ ratio of 0.708 , corresponding to late Jurassic - early Cretaceous $\left(\mathrm{J}_{3}-\mathrm{K}_{1}\right)$ in agreement with previously reported data. The corresponding $\mathrm{Nd}$ isotopic compositions expressed as $\varepsilon_{\mathrm{Nd}}(157 \mathrm{Ma})$ vary from $-8,27$ to 2.32 and the $\mathrm{Nd}$ model ages are Mesoproterozoic, ranging from 1 to $1.3 \mathrm{Ga}$. This highly enriched magma was postulated to have formed by mixing of a depleted mantle and Mesoproterozoic crustal rocks (for example, granite) following a continental extension event. Mixing between crustal rocks having strontium isotopic ratios of 0.715 and 0.730 and a depleted mantle with ${ }^{87} \mathrm{Sr} /{ }^{86} \mathrm{Sr}$ ratio of 0.703 would occur, respectively, at $3 \div 4 \%$ and $2 \div 5 \%$ to generate the observed strontium isotopic ratios in the Tram Tau volcanic rocks.
\end{abstract}

Keywords: Tram Tau, Tu Le Basin, NW Viet Nam, isotopic mixing, geochemistry.

(C2016 Vietnam Academy of Science and Technology

\section{Introduction}

Intraplate rifting structures such as Song $\mathrm{Da}$ - Tu Le and Song Hien are important units in the tectonic framework of northern Viet Nam in the Late Permian - Early Mesozoic (Tran and Tran, 2009). The Tu Le Basin, termed as intraplate rift (Dovjikov et al., 1965; Tran and Nguyen, 1979, 1988; Vu and

*Corresponding author, Email: hoang_geol@hotmail.com
Bui, 1989; Dao and Huynh, 1995) located to the northeast of the Song Da rift (Figure 1) is a dependent trough-shaped basin, formed in the Mesozoic (Hutchison, 1989; Nguyen and Tran, 1992) with a total thickness reaching up to 5000 m (Phan, 1977; Nguyen, 1978). The lower section of the basin is filled with Jurassic - Cretaceous red sediments, while the upper section is comprised by volcanic rocks having contrasting compositions including rhyolite, trachyte and basalt, where alkaline 
N. Hoang, et al./Vietnam Journal of Earth Sciences 38 (2016)

rhyolite, rhyo-trachyte and trachyte are dominant. Plutonic magmatic rocks such as gabbro, syenite, granosyenite, sub-alkaline and alkaline granite are minor and found at Phu Sa Phin and elsewhere in the Tu Le Basin (Nguyen et al., 1995).
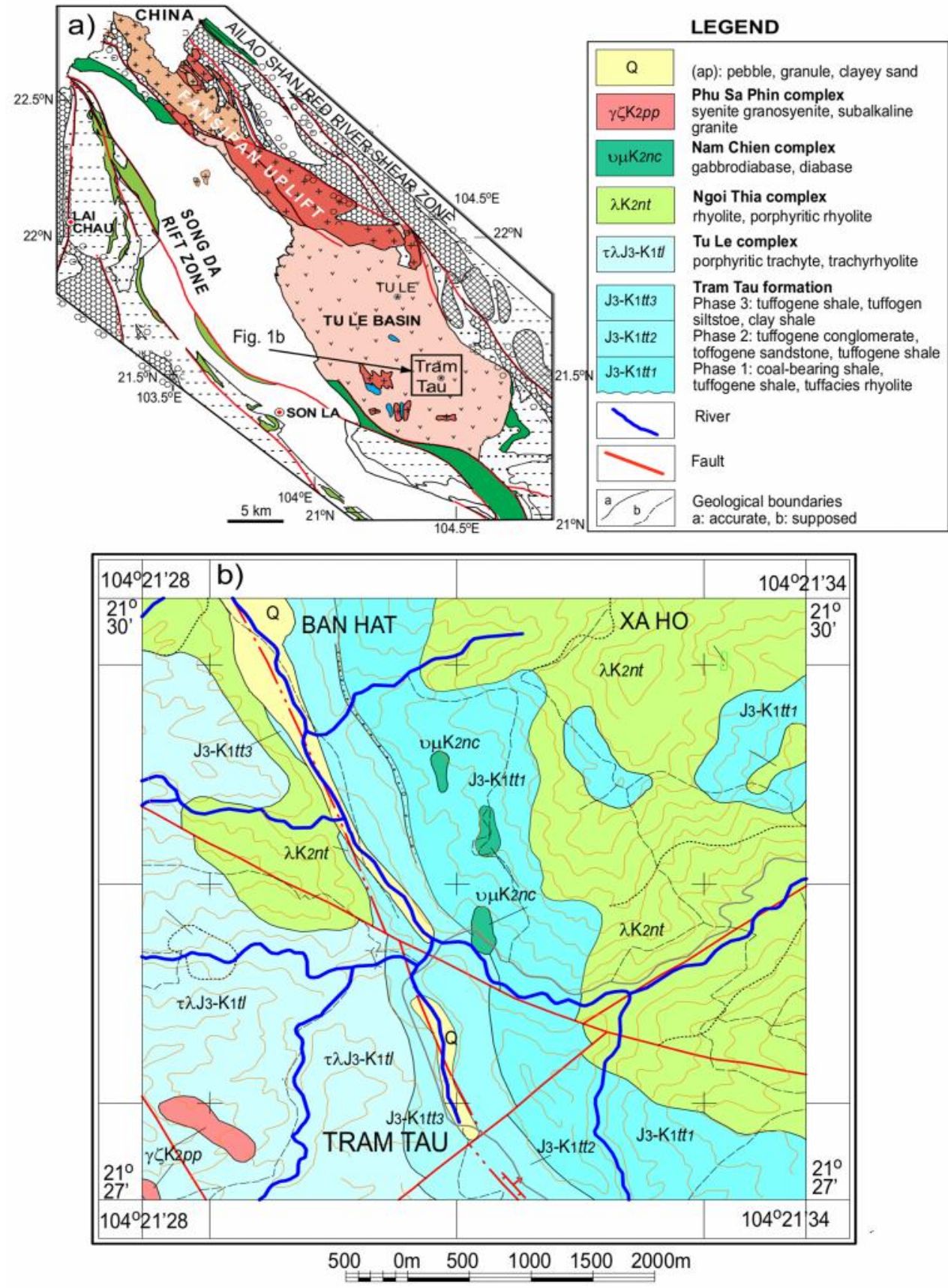

Figure 1. a) Schematic illustration of major tectonic units in NW Viet Nam, showing Ailao Shan Red River Tertiary Shear zone, Fan Si Pan Uplift terrain, Song Da Permian-Triassic plutonic-volcanic rift zone and Tu Le Mesozoic Volcanic Basin. Simplified from Tran et al. (2004); (b) geological scheme of Tram Tau district; sampling route started from Xa Ho to Ban Hat Liu to Tram Tau town, along the intervillage road. Simplified from Yen Bai geological sheet at 1:200,000 after Nguyen Vinh (2005) 
The magmatic formations in the $\mathrm{Tu}$ Le Basin are divided into two sub-alkaline and alkaline pluton-volcanic mafic and felsic series. According to Nguyen et al. (1995, 1997) magmatism in the Tu Le Basin occurred at many successive stages, showing characteristic syn- pluton volcanic activity, on the one hand, and clearly contrasting compositions, on the other. Examples include alkaline mafic - silicic volcanic rocks in the Ban Hat village (Phan, 1977; Nguyen et al., 2000) and late Jurassic - Early Cretaceous sub-alkaline syn- pluton - volcanic mafic silicic rocks of Nam Chien and Phu Sa Phin complexes (Tran, 1996; Vu and Tran, 2007), and alkaline volcanism of Ngoi Thia complex (Phan, 1977). The end of the Tu Le intraplate rifting was marked by the appearance of sole Al-oversaturated sub-alkaline granitoidic magmatism of Ye Yen Sun complex in early Paleogene (Nguyen and Tran, 1992; Tran et al., 2002, and references therein).

Alkaline and sub-alkaline pluton-volcanic felsic complexes classified as JurassicCretaceous Ngoi Thia and Tu Le $(\tau \lambda \mathrm{J}-\mathrm{K} t l)$ complexes (Dovjikov et al., 1965; Phan, 1977; Nguyen, 1978; Vu et al., 1989; Nguyen et al., 2000, 2003; Tran et al., 2004; Tran and Tran, 2009; Pham et al., 2000; Tran, 2011) are exposed in the Tram Tau district, Yen Bai province (Figure 1). A large set of rhyolite, rhyo-trachyte and trachyte samples was collected along two cross-sections along the stream near the Hat Liu Commune administration building to Xa Ho commune, Tram Tau district. Additional samples along with (rare) fresh basalts were collected at outcrops from Ban Hat communal headquarter toward the provincial route leading to Tram Tau town with a total length about $5 \mathrm{~km}$. The samples were processed for petrographic study, and age, geochemical and isotope data acquisition and interpretation for magma source character and related mantle dynamic processes of the $\mathrm{Tu}$ Le pluton-volcanic complex.

\section{Petrography}

Rhyolite, rhyo-trachyte, trachyte samples were collected along two cross-sections, along the inter-village road from the Ban Hat bridge to $\mathrm{Xa} H o$ village; additional samples, including basalts, were sampled at outcrops along Ban Hat village administrative building toward the intersection leading to Tram Tau town (Figure 1) in a total length of nearly $5 \mathrm{~km}$. The rhyolite, rhyo-trachyte, trachyte and (rare) basalt are porphyritic. The rhyolite is grayish white, rosy white, relatively fresh. The phenocrysts including K-feldspar and quartz take up to $30 \%$ of the total rock volume. The feldspar is idiomorphic, with sizes up to $0.5 \times 1 \mathrm{~mm}$. Quartz phenocrysts, up to 15 vol.\% (sample 120405-3), are mostly sub-idiomorphic, sometimes irregularly fragmented, with sizes up to $1 \times 1 \mathrm{~mm}$. The groundmass is trachytic, containing microlites of quartz, biotite, and small amounts of $\mathrm{K}$ feldspar and volcanic glass (Figure 2a, b).

The trachyte is gray, murky white or rosy white, having lesser phenocrysts compared with the porphyritic rhyolite. K-feldspar is the only phenocryst, and up to $1 \times 1.8 \mathrm{~mm}$ in dimension, occupying volumes ranging from $5 \%$ to $15 \%$. The groundmass is trachytic, consisting of microlites of K-feldspar, hydrous mica (or biotite?), and a minor amount of quartz and secondary carbonate minerals.

The basalt (diabase?) (Figure 2c) is black, sometimes greenish black with plagioclase and clinopyroxene in the phenocryst phase (ca. 7 vol.\%). The plagioclase phenocrysts are elongated up to $2 \mathrm{~mm}$ long, randomly distributed among the clinopyroxene phenocrysts, which are irregularly tabularshaped, about $0.1 \times 0.3 \mathrm{~mm}$ in dimension. Secondary minerals include epidote, chlorite, sericite and calcite, which appear as aggregates in the groundmass. 
Vietnam Journal of Earth Sciences 38(3), 242-255
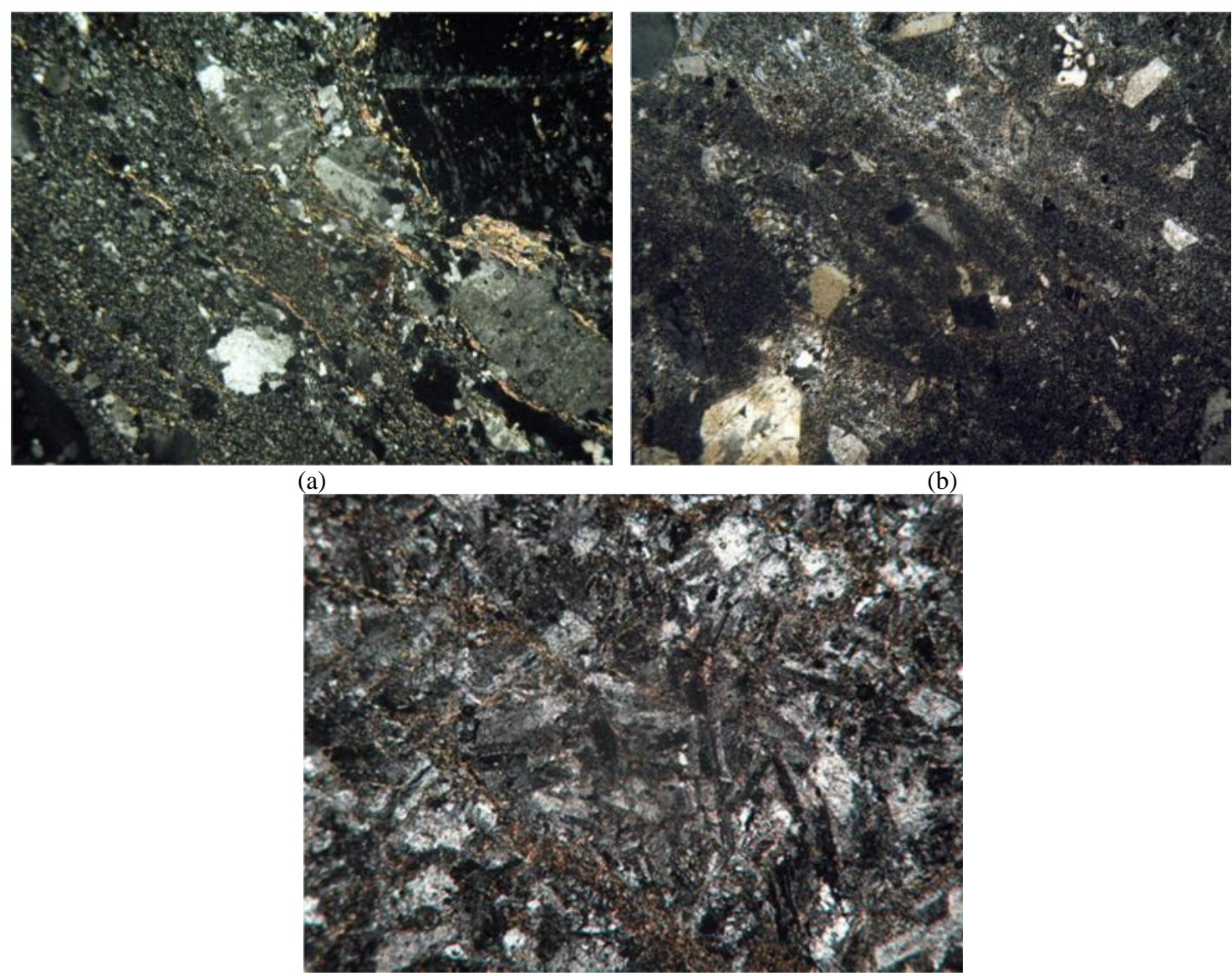

(c)

Figure 2. Photomicrographs from thin sections of Tram Tau volcanic rocks showing porphyritic rhyolite with $\mathrm{K}$-feldspar and quartz phenocrysts $(\mathrm{a}, \mathrm{b})$; elongated plagioclase and small tabular clinopyroxene in doleritic texture of basalt (c)

\section{Sample preparation and analytical procedures}

\subsection{Sample preparation}

About $50 \mathrm{~g}$ of fresh sample was chosen for geochemical and isotopic analysis. The samples were crushed to $<2 \mathrm{~mm}$, then washed in an ultrasonic bath for about 30 minutes, followed by repeated rinsing with purified water before being dried overnight in an oven at about $100^{\circ} \mathrm{C}$. Loss on ignition was calculated using about $2 \mathrm{~g}$ of powder, baked in an oven at $1050^{\circ} \mathrm{C}$ for about one hour.

\subsection{Analysis of major and trace elements}

The analysis for major elements were obtained from fused glass beads using a XRF Bruker Pioneer analyzer at the Institute of
Geological Sciences, Vietnam Academy of Science and Technology (VAST). Geological standards JP-1, JB-1a, JB-3, JA-1, JA-2, JG-1, JR-1 and JR-3 provided by the Geological Survey of Japan (GSJ) were employed for the analytical calibration, and the accuracy evaluation, which is better than $\pm 5 \%$. The trace elements were analyzed by inductively coupled plasma mass spectrometry (ICP-MS) using an Agilent 8800 ICP-MS at GSJ. The trace element analytical procedures and running parameters were similar to those described in Ishizuka et al. (2003). Reproducibility of this method is better than $\pm 4 \%$ for rare earth elements, $\mathrm{Rb}$ and $\mathrm{Nb}$, and better than $\pm 6 \%$ for other elements. Data are shown in Table 1. 
Vietnam Journal of Earth Sciences 38(3), 242-255

Table 1. Major and trace element compositions, and $\mathrm{Rb}-\mathrm{Sr}$, Sm-Nd isotopic ratios of representative samples from Ban Hat Liu, Tram Tau (Tu Le Basin)

\begin{tabular}{|c|c|c|c|c|c|c|}
\hline Sample ID & $120405-1$ & $120405-2$ & $120405-3$ & $120405-8$ & 03032013-7 & $03032013-5$ \\
\hline Longitude & E2378075 & E2378193 & E2378321 & E2377766 & E2374474 & E2376010 \\
\hline Latitude & N0433692 & N0433874 & N0433875 & N0434426 & N0436073 & N0435090 \\
\hline Rock type & Rhyolite & Rhyolite & Rhyolite & Rhyolite & Trachyte & Basalt \\
\hline $\mathrm{SiO}_{2}$ & 72.94 & 72.19 & 72.78 & 76.66 & 67.56 & 52.08 \\
\hline $\mathrm{TiO}_{2}$ & 0.45 & 0.44 & 0.42 & 0.28 & 0.99 & 2.62 \\
\hline $\mathrm{Al}_{2} \mathrm{O}_{3}$ & 12.72 & 12.85 & 12.79 & 10.97 & 21.64 & 17.08 \\
\hline $\mathrm{FeO}^{*}$ & 3.09 & 2.98 & 3.11 & 2.73 & 2.52 & 8.14 \\
\hline $\mathrm{MnO}$ & 0.01 & 0.04 & 0.04 & 0.07 & 0.01 & 0.11 \\
\hline $\mathrm{MgO}$ & 0.51 & 0.24 & 0.24 & 0.26 & 0.65 & 8.12 \\
\hline $\mathrm{CaO}$ & 0.08 & 0.78 & 0.58 & 0.26 & 0.02 & 1.80 \\
\hline $\mathrm{Na}_{2} \mathrm{O}$ & 1.60 & 2.30 & 2.11 & 1.25 & 0.16 & 3.19 \\
\hline $\mathrm{K}_{2} \mathrm{O}$ & 7.66 & 6.82 & 6.85 & 6.30 & 6.38 & 6.15 \\
\hline $\mathrm{P}_{2} \mathrm{O}_{5}$ & 0.04 & 0.06 & 0.06 & 0.02 & 0.08 & 0.71 \\
\hline LOI & 0.88 & 1.28 & 1.03 & 1.21 & 1.10 & 0.65 \\
\hline Sum & 100 & 100 & 100 & 100 & 100 & 100 \\
\hline $\mathrm{Rb}(\mathrm{ppm})(* *)$ & 174.576 & 147.227 & 169.898 & 208.442 & 195.024 & \\
\hline $\mathrm{Sr}(\mathrm{ppm})(\dagger)$ & 13.665 & 21.668 & 18.024 & 10.201 & 21.352 & 139.004 \\
\hline${ }^{87} \mathrm{Rb} /{ }^{86} \mathrm{Sr}$ & 36.9666 & 19.6608 & 27.3117 & 59.1313 & 26.4283 & 51.682 \\
\hline$\left({ }^{87} \mathrm{Sr} /{ }^{86} \mathrm{Sr}\right)_{\mathrm{m}}$ & 0.788251 & 0.752829 & 0.768902 & 0.841203 & 0.767512 & 7.7824 \\
\hline $2 \sigma( \pm)$ & 0.000008 & 0.000008 & 0.000010 & 0.000008 & 0.000008 & 0.725747 \\
\hline$\left({ }^{87} \mathrm{Sr} /{ }^{86} \mathrm{Sr}\right)_{\mathrm{i}}$ & 0.705837 & 0.708998 & 0.708014 & 0.709389 & 0.708586 & \\
\hline$\varepsilon_{\mathrm{Sr}}(\mathrm{t}=157 \mathrm{Ma})$ & 19.0 & 63.8 & 49.9 & 69.4 & 58.0 & \\
\hline $\mathrm{Sm}(\mathrm{ppm})(* *)$ & 8.117 & 19.028 & 12.680 & 21.214 & 27.991 & 7.597 \\
\hline $\mathrm{Nd}(\mathrm{ppm})(\dagger)$ & 39.958 & 114.495 & 50.640 & 106.223 & 141.148 & 41.795 \\
\hline${ }^{147} \mathrm{Sm} /{ }^{144} \mathrm{Nd}$ & 0.12706 & 0.10395 & 0.15662 & 0.12491 & 0.12403 & 0.11369 \\
\hline$\left({ }^{143} \mathrm{Nd} /{ }^{144} \mathrm{Nd}\right)_{\mathrm{m}}$ & 0.512521 & 0.512334 & 0.512669 & 0.512574 & 0.512476 & 0.512269 \\
\hline $2 \sigma( \pm)$ & 0.000010 & 0.000006 & 0.000006 & 0.000007 & 0.000006 & 0.000008 \\
\hline$\left({ }^{143} \mathrm{Nd} /{ }^{144} \mathrm{Nd}\right)_{\mathrm{i}}$ & 0.512238 & 0.512102 & 0.512320 & 0.512296 & 0.512200 & \\
\hline$\varepsilon_{\mathrm{Nd}}(157 \mathrm{Ma})$. & -3.93 & -6.57 & -2.32 & -2.79 & -4.67 & \\
\hline $\mathrm{T}_{(\mathrm{DM})}(\mathrm{Ga})$ & 1.1 & 1.1 & 1.3 & 0.99 & 1.1 & \\
\hline
\end{tabular}

Remarks: $\mathrm{FeO}^{*}=0.85 \times\left(\mathrm{FeO}+\mathrm{Fe}_{2} \mathrm{O}_{3}\right) ;(* *)$ analyzed by ICP-MS, $(\dagger)$ by isotope dilution; m: measured, i: initialized for $\left.\left.\mathrm{t}=157 \mathrm{Ma} ; \varepsilon_{\mathrm{Sr}(\mathrm{t})}=\left[\left({ }^{87} \mathrm{Sr} /{ }^{86} \mathrm{Sr}\right)_{\mathrm{i}} / 0.7045\right)-1\right] \times 10^{4}, \mathrm{t}=157 \mathrm{Ma} ; \varepsilon_{\mathrm{Nd}(\mathrm{t})}=\left[\left({ }^{143} \mathrm{Nd} /{ }^{144} \mathrm{Nd}\right)_{\mathrm{m}} / 0.512439\right)-1\right] \times 10^{4}$; 0.512439 is CHUR's (Chondrite Uniform Reservoir) ${ }^{143} \mathrm{Nd} /{ }^{144} \mathrm{Nd}$ at $\mathrm{t}=157 \mathrm{Ma}$ (present value is 0.512638 ); $\mathrm{T}$ (depleted) model age $=1 / \lambda \times \ln \left\{1+\left[\left({ }^{143} \mathrm{Nd} /{ }^{144} \mathrm{Nd}\right)_{\mathrm{m}}\right)-0.51315\right] /\left[\left({ }^{147} \mathrm{Sm} /{ }^{144} \mathrm{Nd}\right)_{\mathrm{m}^{-}}-0.2135\right]$, where 0.51315 and 0.2135 are ${ }^{143} \mathrm{Nd} /{ }^{144} \mathrm{Nd}$ and ${ }^{147} \mathrm{Sm} /{ }^{144} \mathrm{Nd}$ for present depleted mantle; $\lambda$ : decay constant of ${ }^{147} \mathrm{Sm}$ to ${ }^{143} \mathrm{Nd},=6.54 \times$ $10^{-12}$; LOI: loss on ignition; The basalt (diabase) sample (03032013-5) of unknown origin is not used for isochron construction

\subsection{Analysis of Sr and $\mathrm{Nd}$ isotopes}

For $\mathrm{Sr}$ and $\mathrm{Nd}$ isotopic analysis, about $20 \mathrm{~g}$ of the cleaned chipped samples were washed in purified $\mathrm{HCl} 6 \mathrm{~N}$ to eliminate secondary minerals (chlorite, carbonate, etc.). The samples were rinsed with clean water and dried in an oven at about $100^{\circ} \mathrm{C}$. About $2 \mathrm{~g}$ of each processed sample were ground in an agate mill, then about $50 \mathrm{mg}$ of the powder was weighed in a $15 \mathrm{ml}$ Teflon beaker to be dissolved using concentrated $\mathrm{HNO}_{3}$ and $\mathrm{HF}$ (ratio 1:2) on a hotplate for about 48 hours. After evaporation the samples were ready for anion exchange column chemistry.

Sr element was extracted using Sr-spec resin from Eichrom. Details of this procedure are described in Hoang and Uto (2006). Acids used for $\mathrm{Sr}$ extraction were $\mathrm{HNO}_{3}$, having molarities varying between 0.05 and $7.5 \mathrm{~N}$. Solutions collected before $\mathrm{Sr}$ extraction were used for extraction of $\mathrm{Nd}$ and $\mathrm{Sm}$ using AG50W8X 200-400 resin followed by Lnresin (Eichrom). 
N. Hoang, et al./Vietnam Journal of Earth Sciences 38 (2016)

The isotopic ratios were measured on a 9- The reproducibility values of ${ }^{87} \mathrm{Sr} /{ }^{86} \mathrm{Sr}$ Faraday collector VG Sector 54 thermal and ${ }^{143} \mathrm{Nd} /{ }^{144} \mathrm{Nd}$ ratios are, respectively, ionization mass spectrometer (TIMS) at GSJ. $\quad \pm 0.000007$ and $\pm 0.00001- \pm 0.000006$. $\mathrm{Sr}$ and $\mathrm{Nd}$ isotope running parameters were The isotopic compositions are shown in described in Hoang and Uto (2006). Table 1.

Table 1 (continued). Trace element compositions of representative volcanic samples from Ban Hat Liu, Tram Tau (Tu Le Basin)

\begin{tabular}{|c|c|c|c|c|c|c|}
\hline Sample ID & $120405-1$ & $120405-2$ & $120405-3$ & $120405-8$ & 03032013-7 & 03032013-5 \\
\hline Rock type & Rhyolite & Rhyolite & Rhyolite & Rhyolite & Trachyte & Basalt \\
\hline \multicolumn{7}{|l|}{$(\mathrm{ppm})^{*}$} \\
\hline $\mathrm{Rb}$ & 174.58 & 147.23 & 169.90 & 208.44 & 195.50 & 148.89 \\
\hline $\mathrm{Sr}$ & 8.47 & 22.54 & 14.53 & 11.12 & 20.35 & 47.56 \\
\hline $\mathrm{Zr}$ & 86.06 & 83.12 & 153.59 & 598.97 & 1.499 .28 & 36.58 \\
\hline $\mathrm{Nb}$ & 161.27 & 144.50 & 110.43 & 202.14 & 305.94 & 54.25 \\
\hline $\mathrm{Cs}$ & 0.48 & 0.53 & 0.52 & 0.76 & 3.405 & 6.964 \\
\hline $\mathrm{Ba}$ & 218.34 & 452.19 & 537.84 & 138.56 & 1.005 .23 & 629.57 \\
\hline $\mathrm{Hf}$ & 2.34 & 2.22 & 4.13 & 15.72 & 36.27 & 0.92 \\
\hline $\mathrm{Ta}$ & 9.95 & 9.01 & 7.99 & 14.84 & 22.02 & 3.87 \\
\hline $\mathrm{Pb}$ & 3.63 & 4.87 & 4.70 & 3.33 & 25.49 & 2.89 \\
\hline Th & 31.71 & 24.81 & 20.49 & 29.30 & 53.52 & 4.20 \\
\hline $\mathrm{U}$ & 8.74 & 5.07 & 3.88 & 6.61 & 10.96 & 0.74 \\
\hline $\mathrm{V}$ & 13.48 & 10.92 & 7.13 & 0.27 & 26.85 & 196.04 \\
\hline $\mathrm{Cr}$ & 41.62 & 75.02 & 125.46 & 62.13 & 13.38 & 121.34 \\
\hline $\mathrm{Ni}$ & 18.58 & 32.67 & 55.35 & 33.16 & 11.38 & 86.39 \\
\hline $\mathrm{La}$ & 30.61 & 151.00 & 58.19 & 116.42 & 165.02 & 45.91 \\
\hline $\mathrm{Ce}$ & 69.94 & 300.32 & 165.12 & 244.30 & 330.09 & 92.42 \\
\hline $\operatorname{Pr}$ & 8.41 & 30.91 & 12.29 & 26.00 & 40.61 & 10.36 \\
\hline $\mathrm{Nd}$ & 39.96 & 114.49 & 50.64 & 106.22 & 141.15 & 41.79 \\
\hline $\mathrm{Sm}$ & 12.12 & 19.03 & 12.68 & 21.21 & 27.99 & 7.60 \\
\hline $\mathrm{Eu}$ & 1.07 & 1.37 & 1.15 & 1.40 & 2.38 & 2.41 \\
\hline $\mathrm{Gd}$ & 11.68 & 13.99 & 13.62 & 20.46 & 23.24 & 7.00 \\
\hline $\mathrm{Tb}$ & 2.15 & 2.18 & 2.37 & 3.41 & 4.07 & 0.88 \\
\hline Dy & 13.77 & 11.57 & 13.32 & 19.48 & 23.85 & 3.82 \\
\hline Ho & 2.93 & 2.40 & 2.77 & 4.00 & 5.01 & 0.63 \\
\hline $\mathrm{Er}$ & 8.56 & 7.05 & 8.12 & 11.38 & 15.02 & 1.40 \\
\hline $\mathrm{Tm}$ & 1.18 & 1.00 & 1.15 & 1.80 & 2.40 & 0.18 \\
\hline $\mathrm{Yb}$ & 6.99 & 5.76 & 6.92 & 9.94 & 14.79 & 0.96 \\
\hline $\mathrm{Lu}$ & 0.75 & 0.74 & 0.90 & 1.33 & 2.11 & 0.15 \\
\hline $\mathrm{Y}$ & 68.91 & 60.27 & 78.16 & 107.24 & 121.33 & 15.91 \\
\hline
\end{tabular}

Remark: (*) Analyzed by Agilent 8800 ICP-MS at the Geological Survey of Japan. Error (\%) from \pm 2 to \pm 6 for rare earth and LIL elements, for $\mathrm{Nb}$ and $\mathrm{Ta}$ is $\pm 5 \%$

\subsection{Analysis of Sr and $\mathrm{Nd}$ isotopes}

For $\mathrm{Sr}$ and $\mathrm{Nd}$ isotopic analysis, about $20 \mathrm{~g}$ of the cleaned chipped samples were washed in purified $\mathrm{HCl} 6 \mathrm{~N}$ to eliminate secondary minerals (chlorite, carbonate, etc.). The samples were rinsed with clean water and dried in an oven at about $100^{\circ} \mathrm{C}$. About $2 \mathrm{~g}$ of each processed sample were ground in an agate mill, then about $50 \mathrm{mg}$ of the powder was weighed in a $15 \mathrm{ml}$ Teflon beaker to be dissolved using concentrated $\mathrm{HNO}_{3}$ and $\mathrm{HF}$ (ratio 1:2) on a hotplate for about 48 hours. After evaporation the samples were ready for anion exchange column chemistry.

$\mathrm{Sr}$ element was extracted using $\mathrm{Sr}$-spec resin from Eichrom. Details of this procedure are described in Hoang and Uto (2006). Acids used for Sr extraction were $\mathrm{HNO}_{3}$, having molarities varying between 0.05 and $7.5 \mathrm{~N}$. Solutions collected before $\mathrm{Sr}$ extraction were used for extraction of Nd and Sm using AG50W8X 200-400 resin followed by Ln-resin (Eichrom). 
The isotopic ratios were measured on a 9 Faraday collector VG Sector 54 thermal ionization mass spectrometer (TIMS) at GSJ. $\mathrm{Sr}$ and $\mathrm{Nd}$ isotope running parameters were described in Hoang and Uto (2006). The reproducibility values of ${ }^{87} \mathrm{Sr} /{ }^{86} \mathrm{Sr}$ and ${ }^{143} \mathrm{Nd} /{ }^{144} \mathrm{Nd}$ ratios are, respectively, \pm 0.000007 and $\pm 0.00001- \pm 0.000006$. The isotopic compositions are shown in Table 1.

\section{Analytical results}

\subsection{Major and trace element compositions}

The Tram $\mathrm{Tau} \mathrm{SiO}_{2}$ contents vary from 49 wt. $\%$ to $75 \mathrm{wt} . \%$ with the total alkaline oxides (e.g. $\mathrm{Na}_{2} \mathrm{O}+\mathrm{K}_{2} \mathrm{O}$ ) from 3.2 to 9 wt.\%. The samples, with rhyolite as dominant rock type, plot mainly in the alkaline field in $\mathrm{SiO}_{2}$ vs. $\left(\mathrm{Na}_{2} \mathrm{O}+\mathrm{K}_{2} \mathrm{O}\right)$ diagram (Figure 3, after Le Bas et al., 1986). Chondrite normalized rare earth element (e.g. Anders and Grevesse, 1989) and primitive mantle (e.g. Sun and McDonough, 1989) trace element normalized patterns of the Tram Tau volcanic rocks are shown in Figures $4 \mathrm{a}$ and $4 \mathrm{~b}$, respectively. The rhyolite and trachyte contain high trace element concentrations relative to chondritic and primitive mantle values, although showing strong negative anomalies for $\mathrm{Ba}, \mathrm{Sr}, \mathrm{Eu}$ and
Ti. The negative anomalies may reflect fractional crystallization of plagioclase and feldspar (for $\mathrm{Sr}$ and $\mathrm{Eu}$ ), olivine, pyroxene and, especially amphibole (for $\mathrm{Ba}$ and $\mathrm{Ti}$ ) (e.g. Ionov and Hofmann, 1995). These geochemical features have been described in detail elsewhere in the literature (e.g. Nguyen et al., 1995; 1996; Tran, 1996; Tran et al., 2004, 2009, 2011). The basalt, on the other hand, is relatively depleted, showing low trace element abundances (Table 1) and having flat distribution pattern.

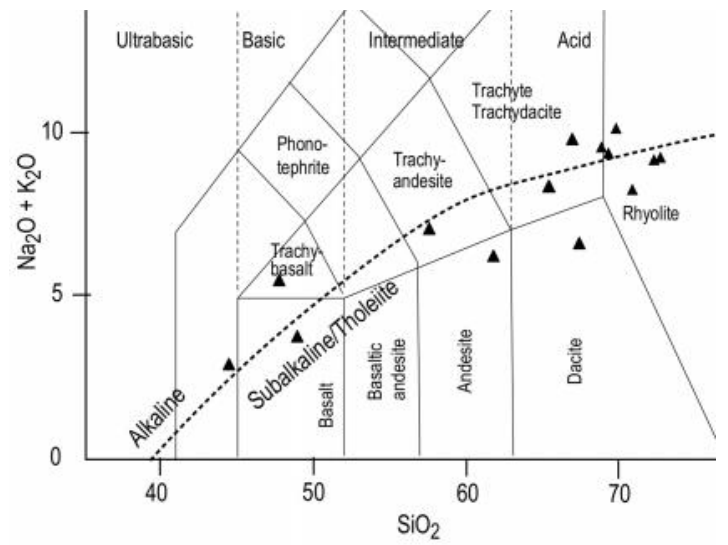

Figure 3. $\mathrm{SiO}_{2}$ vs. $\left(\mathrm{Na}_{2} \mathrm{O}+\mathrm{K}_{2} \mathrm{O}\right)$ classification diagram (after Le Bas et al., 1986) showing the majority of Tram Tau (Tu Le Basin, in general) samples are alkaline felsic type
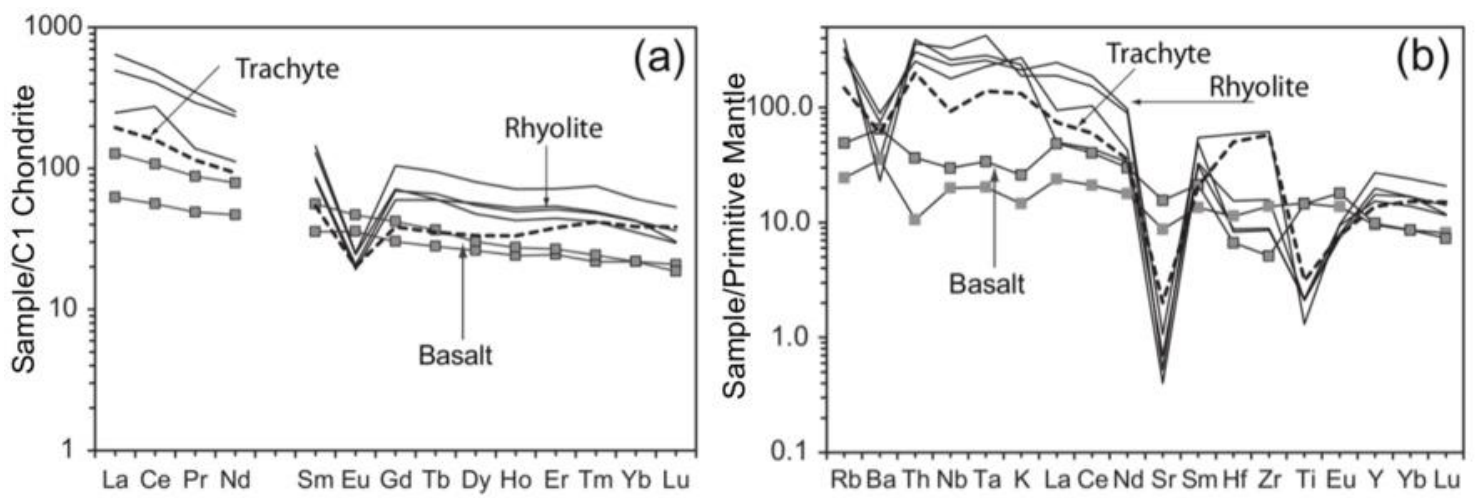

Figure 4. (a) Chondrite normalized rare earth element distribution patterns (after Anders and Grevesse, 1989) and (b) Primitive mantle normalized trace element (after Sun and McDonough, 1989) showing relative depletion of Ba, $\mathrm{Eu}$, and $\mathrm{Ti}(\mathrm{b})$ and overall enrichment of all other elements

\section{2. ${ }^{87} \mathrm{Rb} /{ }^{86} \mathrm{Sr} v \mathrm{vs} .{ }^{87} \mathrm{Sr} /{ }^{86} \mathrm{Sr}$ isochron}

rhyo-trachyte and trachyte, and a basalt

A set of five samples including rhyolite, (120405-1, 120405-2, 120405-3, 120405-8, 03032013-7, and 03032013-5) were collected 
N. Hoang, et al./Vietnam Journal of Earth Sciences 38 (2016)

in the same outcrop near the Ban Hat bridge (Figure 1) for $\mathrm{Rb} / \mathrm{Sr}$ age dating analysis. The $\mathrm{Rb}$ and $\mathrm{Sr}$ element contents were obtained both by isotope dilution and ICP-MS for comparison. The ${ }^{87} \mathrm{Sr} /{ }^{86} \mathrm{Sr}$ isotopic ratios of the samples were repeatedly run and the accuracy and precision were monitored by reference to measurements of NBS987 $\mathrm{Sr}$ isotopic standard. The ${ }^{87} \mathrm{Rb} /{ }^{86} \mathrm{Sr}$ were calculated based on the $\mathrm{Rb}$ and $\mathrm{Sr}$ concentrations by the following equation:

${ }^{87} \mathrm{Rb} /{ }^{86} \mathrm{Sr}=\mathrm{Rb} / \mathrm{Sr}(\mathrm{ppm}) \times\left(\mathrm{A} b^{87} \mathrm{Rb} \quad \mathrm{x}\right.$ $W \mathrm{Sr}) /\left(\mathrm{A} b^{86} \mathrm{Sr} \times W \mathrm{Rb}\right)$

Where

$\mathrm{A} b{ }^{87} \mathrm{Rb}=\%$ isotope ${ }^{87} \mathrm{Rb}$ in total $\mathrm{Rb}=$ $27.835 \%$

$\mathrm{A} b{ }^{86} \mathrm{Sr}=\%$ isotope ${ }^{86} \mathrm{Sr}$ in total $\mathrm{Sr}=$ $9.8615 \%$

$W \mathrm{Rb}=$ atomic weight of ${ }^{87} \mathrm{Rb}=85.468$

$W \mathrm{Sr}=$ atomic weight of ${ }^{86} \mathrm{Sr}=87.617$.

The results are shown in Table 1 . The ${ }^{87} \mathrm{Rb} /{ }^{86} \mathrm{Sr}$ isotopic ratios vary from 7.782 to 59.131 corresponding to ${ }^{87} \mathrm{Sr} /{ }^{86} \mathrm{Sr}$ varying from 0.7257 to 0.8412 . Using Isoplot v. 4.1 by Ludwig (2012) for Excel 2010, plots of ${ }^{87} \mathrm{Rb} /{ }^{86} \mathrm{Sr}$ vs. ${ }^{87} \mathrm{Sr} /{ }^{86} \mathrm{Sr}$ form an isochron corresponding to $157 \pm 2.9 \mathrm{Ma}$ (late Jurassic early Cretaceous) and an initial ${ }^{87} \mathrm{Sr} /{ }^{86} \mathrm{Sr}$ ratio of 0.708 (Figure 5).

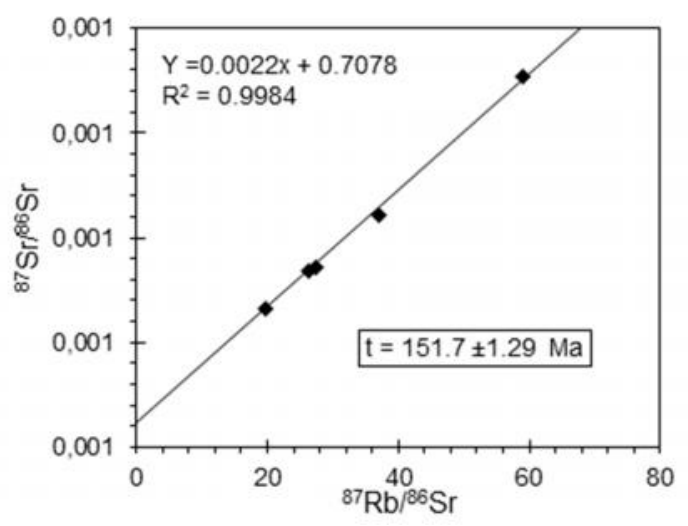

Figure 5. Plots of ${ }^{87} \mathrm{Rb} /{ }^{86} \mathrm{Sr}$ vs. ${ }^{87} \mathrm{Sr} /{ }^{86} \mathrm{Sr}$ (after Ludwig, 2012) of a set of samples (Table 2) collected in the Ban Hat Liu village forming an isochron of $157 \pm 2.9 \mathrm{Ma}$ and an initial ${ }^{87} \mathrm{Sr} /{ }^{86} \mathrm{Sr}$ isotopic ratio of 0.708

\section{Discussion}

\subsection{Regional tectonic - magma evolution}

Tapponnier et al. (1982, 1990, 2001) suggested that Indochina was rotated clockwise while being extruded eastward along the Ailao Shan - Red River Shear zone (ASRRSZ) following the Indo - Eurasian collision in early Tertiary leading to the opening of (Viet Nam) East Sea (South China Sea) between 30 and $17 \mathrm{Ma}$ (Tapponnier and Molnar, 1977; Tapponnier et al., 1982, 1990, 2001). Therefore, the ASRRSZ has been viewed as a suture zone between south China and Indochina (Leloup et al., 1995). With the aim of studying paleogeography in southern Chinese regions Gilder et al. (1996) conducted paleomagnetic, $\mathrm{Rb}-\mathrm{Sr}$ and $\mathrm{Sm}-\mathrm{Nd}$ isotopic measurements on samples collected from 23 Mesozoic granite outcrops in western Yunnan, China. They discovered that Mesozoic regional faults in southern China were mostly left lateral strike slips that activated simultaneously with intraplate extension as continental blocks having similar crustal structure moving northward (Gilder et al., 1996). These Mesozoic intraplate extension-induced granites are anomalously rich in $\mathrm{Nd}(>45 \mathrm{ppm})$ and $\mathrm{Sm}(>8 \mathrm{ppm})$, which reflect the difference between blocks extruded southeastward and those that remained stable in the north (Gilder et al., 1996). Following Gilder et al. (1996), while studying the relationship between geological and magmatic formations in northwest Yunnan and northwest Viet Nam, Chung et al. (1997) suggested that since the ASRRSZ is located in the South China continent, therefore the shear zone should not be viewed as a suture zone separating south China and Indochina as previously thought. These authors suggested that the boundary between the two blocks must be further south, possibly along the Song Ma ophiolite belt (Chung et al., 1997). According to these authors, 
following the India - Eurasian collision, a number of geological formations were extruded about $600-700 \mathrm{~km}$ from northwest Yunnan southeastward, to northwest Viet Nam, along this suture zone; also, the plate collision and collision-induced intraplate extension and spreading of (Viet Nam) East Sea about 30 million years ago could serve as the principal cause of the ASRRSZ formation.

Accordingly, Lan et al. (2000 and references therein), on the basis of $\mathrm{Sr}$ and $\mathrm{Nd}$ isotopic characteristics, suggested that the Po Sen (Middle Proterozoic), Dien Bien (Permian - Triassic), Tu Le rhyolite and Phu Sa Phin granite complex $\left(\mathrm{J}_{3}-\mathrm{K}\right)$, south of $\mathrm{Tu} \mathrm{Le}$ Basin, may belong to the same plutonicvolcanic association. Because the Phu Sa Phin granite and $\mathrm{Tu}$ Le rhyolite show $\varepsilon_{\mathrm{Nd}(\mathrm{t}=145 \mathrm{Ma})}$ between -2.8 and +0.6 , and the neodymium model ages $\left(\mathrm{T}_{\mathrm{DM}}\right)$ between 0.6 and $1.1 \mathrm{Ga}$, with the Sm varying from 17 to $30 \mathrm{ppm}$ and corresponding $\mathrm{Nd}$ varying between 120 and $240 \mathrm{ppm}$; this plutonic-volcanic association may be produced by intraplate extension in south China (Yunnan) having been transported to the present location by lithospheric extrusion along the ASRRSZ following the collision between India and Eurasia (e.g. Leloup et al., 1995; Chung et al., 1997; Lan et al., 2000; after Tapponnier et al., 1990 and Gilder et al., 1996).

In contrast to Lan et al. (2000) and previously reported late Jurassic - early Cretaceous ages (see above), Ngoi Thia and $\mathrm{Tu}$ Le magmatic rocks have recently been determined as Permian by U-Pb isotopic age dating in zircons from a Ngoi Thia rhyolite (256 $\pm 4 \mathrm{Ma}$, Nguyen et al., 2003), a Phu Sa Phin granite (261 $\pm 2.8 \mathrm{Ma}$, Tran et al., 2009).

\subsection{Mantle source and magma genesis in the Tu Le basin}

Model ages of the Tu Le rhyolites reported by Lan et al. (2000) vary between 0.6 and 1.1 $\mathrm{Ga}$, corresponding to Mesoproterozoic -
Neoproterozoic. This age indicates that the magma was generated by mixing between Emeishan-type mantle source and crustal material having ages from 600 to 1100 million years by intraplate extension following South China and Indochina plate amalgamation dynamics in early Mesozoic (e.g. Chung and Jahn, 1995; Chung et al., 1998; Tran and Tran, 2011). The initial strontium isotopic ratios (for $157 \mathrm{Ma}$ ) for the Tram Tau samples vary between 0.70584 and $0.70942\left(\varepsilon_{\mathrm{Sr}(\mathrm{t})}\right.$ varies from 19 to 70$)$; and accompanying $\varepsilon_{\mathrm{Nd}(\mathrm{t})}$ varying from -2.32 to -8.27 and the $\mathrm{T}_{(\mathrm{DM})}$ varies from 1 to $1.3 \mathrm{Ga}$, but most about 1.1 $\pm 0.03 \mathrm{Ga}$ (Table 1). These isotopic compositions are too enriched for a mantle source; therefore, there must be some crustal material involved in the Tram Tau magma generation (Figure 6). Assuming the initial ${ }^{87} \mathrm{Sr} /{ }^{86} \mathrm{Sr}$ of Proterozoic crust underneath $\mathrm{Tu}$ Le basin is in the range of that beneath Mesozoic basins in western Yunnan (China) (Gilder et al., 1996) and southeast China (Jahn et al., 1976) between 0.715 and 0.730 , and a depleted mantle being 0.70315 (average of Pacific-MORB, e.g. White et al., 1987); to generate magmatic melts having ${ }^{87} \mathrm{Sr} /{ }^{86} \mathrm{Sr}$ from 0.7058 to 0.7094 , the percentage of the crustal rocks involved in the mixing with the mantle source would be ca. $3 \div 4 \%$ and $2 \div 5 \%$, respectively, (Figure 6). The mixing process could involve mantle upwelling following a lithospheric extension event, triggering decompression melts that interacted with crustal rocks that subsided in gravitational response to the lithospheric extension and mantle upwelling. Under the impact of hot mantle melts, the crustal rocks may be partially melted and incorporated into the mantle melts forming geochemically enriched melts (e.g. Sun and McDonough, 1989) (Figure 4a, b), which underwent fractional crystallization processes on the way to the surface. 
N. Hoang, et al./Vietnam Journal of Earth Sciences 38 (2016)

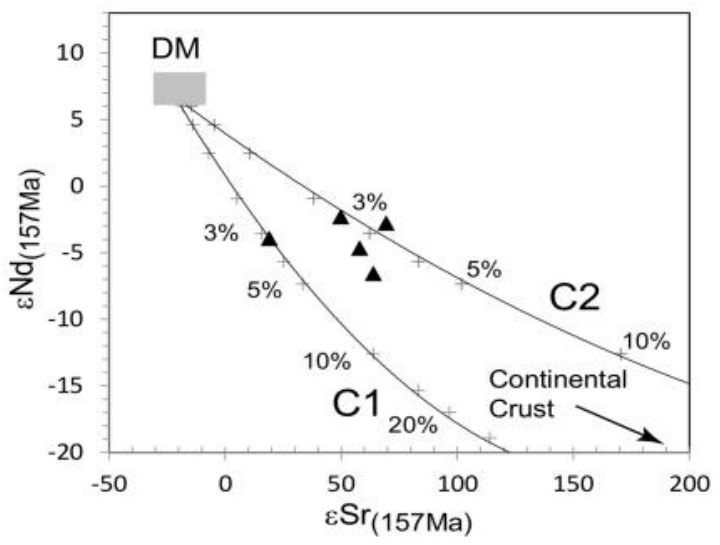

Figure 6. Plots of $\varepsilon_{\mathrm{Nd}(\mathrm{t})}$ vs. $\varepsilon_{\mathrm{Sr}(\mathrm{t})}$ of the Tram Tau volcanic rocks (ca. $157 \mathrm{Ma}$ ). Mixing curves were hypothesized assuming a mantle melt having ${ }^{87} \mathrm{Sr} /{ }^{86} \mathrm{Sr}$ and ${ }^{143} \mathrm{Nd} /{ }^{144} \mathrm{Nd}$ isotopic ratios and $\mathrm{Sr}$ and $\mathrm{Nd}$ elemental contents, respectively, $0.703,0.51315,20$ and 1.354 ppm to mix with 2 different crustal melts, having ${ }^{143} \mathrm{Nd} /{ }^{144} \mathrm{Nd}, \mathrm{Sr}$ and $\mathrm{Nd}$ contents $(\mathrm{ppm})$, respectively, $0.5115\left(\varepsilon_{\mathrm{Nd}}=-22\right), 180$ and 25 ; and ${ }^{87} \mathrm{Sr} /{ }^{86} \mathrm{Sr}$ isotopic ratios for curve (1) and (2), respectively, $0.715\left(\varepsilon_{\mathrm{Sr}}=\right.$ $150), 0.730\left(\varepsilon_{\mathrm{Sr}}=360\right)$. See explanations in the text.

Eruption age of the Tram Tau samples in this study is $157 \pm 2.9 \mathrm{Ma}$, corresponding to late Jurassic - early Cretaceous. This age is in good agreement with many reported radiometric and fossil-base ages (e.g. Nguyen, 1978; Tran et al., 1979; Vu et al., 1989; Nguyen et al., 2000), which also falls in the age interval of Suoi Be complex (176.3 \pm 0.8 , $164 \pm 0.8$, and $117.3 \pm 0.6 \mathrm{Ma}$ ) (Tran et al., 2004).

Pham Duc Luong et al. (2010) extracted zircons from two rhyo-trachytes in the Tu Le complex and three rhyolites in the Ngoi Thia complex for $\mathrm{U}-\mathrm{Pb}$ isotopic age dating using an LA-ICP-MS. Results showed that the trachytes formed around 114 and $116 \mathrm{Ma}$, while the rhyolites erupted at 93, 118 and 256 Ma. On this basis, the authors concluded that plutonic-volcanic igneous activities in the $\mathrm{Tu}$ Le basin may have occurred in a number of episodes, starting from late Permian to late Cretaceous, but mostly during late Jurassic early Cretaceous (Pham et al., 2010).
As mentioned above, the $\varepsilon_{\mathrm{Sr}(\mathrm{t})}$ and $\varepsilon_{\mathrm{Nd}(\mathrm{t})}$, especially the $\mathrm{T}_{(\mathrm{DM})}$ of Tram Tau volcanic rocks are much different from those of Mesozoic type-A granite in southwest Yunnan (and elsewhere in northwest Viet Nam) (e.g. Lan et al., 2000 after Gilder et al., 1996, Chung et al., 1997). The assumption that late Jurassic - early Cretaceous Tu Le volcanic rocks formed in southwest Yunnan by intraplate extension were transported to NW Viet Nam should be further studied for more evidence. Moreover, according to the extrusion tectonic model, left lateral extrusion along the ASRRSZ could have caused Indochina block to rotate clockwise (e.g. Tapponnier et al., 1982). However, there is little evidence that Indochina has rotated significantly to compensate for the displacement of an immense crustal block with a total length of about $600 \mathrm{~km}$ having taken place in about 30 million years (Cung and Dorobek, 2004; Cung and Geissman, 2013). Above all, while the continental extrusion model alone is not ready to explain the East Sea (South China Sea) opening dynamics, trench roll-back and post-IndiaEurasian collision magmatism, alternatively, the mantle extrusion model may account for most of the above phenomena (e.g. Hoang et al., 1996, 2013; Flower et al., 1998, 2001; Royden et al., 2008; Yang and Liu, 2009).

\section{Conclusions}

From the above descriptions we come to the following conclusions:

Volcanic rocks in Ban Hat Liu and Ban Ho, Tram Tau district (Tu Le Basin) are mostly porphyritic rhyolite, rhyo-trachyte, trachyte and subordinate basalt (or diabase). They belong to the alkaline series, having high to very high abundances of trace elements such as $\mathrm{Rb}, \mathrm{Th}, \mathrm{Nb}$, Ta and the rare earths.

The ${ }^{87} \mathrm{Sr} /{ }^{86} \mathrm{Sr}$ isotopic ratios of a set of volcanic samples vary between 0.7257 and 0.8412 forming an isochron that yields an age of $157 \pm 2.9 \mathrm{Ma}$ and an initial ${ }^{87} \mathrm{Sr} /{ }^{86} \mathrm{Sr}$ isotopic 
ratio of 0.708 . This age is in good agreement with previously reported radiometric and fossil-based age data (late Jurassic - early Cretaceous) for volcanic rocks in the area.

$\mathrm{The} \mathrm{Sr}$ and $\mathrm{Nd}$ isotopic compositions of volcanic rocks in the Tram Tau district (and $\mathrm{Tu}$ Le basin, in general) are highly enriched for a mantle source, suggesting involvement of crustal melts. To produce magmatic melts having ${ }^{87} \mathrm{Sr} /{ }^{86} \mathrm{Sr}$ ratio from 0.7058 to 0.7094 , a mantle-derived melt with strontium isotopic ratio of 0.703 has to mix with crustal melts having ${ }^{87} \mathrm{Sr} /{ }^{86} \mathrm{Sr}$ isotopic ratios ranging between 0.715 and 0.730 at a percentage range, respectively, of $3 \div 4 \%$ and $2 \div 5 \%$.

$\mathrm{The} \mathrm{Sr}$ and $\mathrm{Nd}$ isotopic compositions of Tram Tau volcanic rocks are much different from those reported for Mesozoic A-type granites in western Yunnan (Gilder et al., 1996). Along with scanty paleomagnetic evidence of northern Viet Nam's significant extrusion and rotation since the Mesozoic (see above), the model of 600-700 km southeastward extrusion of western Yunnan proposed by Chung et al. (1997) and Lan et al. (2000) would need further investigation.

Regardless of being in good agreement with many previously reported data, in the light of various radiometric age ranges recently reported for Tram Tau felsic volcanic rocks, the $\mathrm{Rb}-\mathrm{Sr}$ isotopic age in this study may be viewed as a reference. We expect to acquire more radiometric age data for the felsic volcanic rocks using more reliable methods.

\section{Acknowledgments}

A Vietnamese version of this manuscript was reviewed by Drs. Nguyen Thanh Van, Tran Trong Hoa and Bui Minh Tam, whose critical comments helped improve the manuscript significantly. This research was conducted under the grant VAST.DTCB.01/12-13 funded by the Vietnam Academy of Science and Technology, to whom we extend our thanks and appreciations. O. Ishizuka and $\mathrm{K}$. Yamanobe (GSJ) are thanked for assistance in the trace element analysis.

\section{References}

Anders, E., Grevesse, N., 1989. Abundances of the elements: meteorite and solar. Geochim. Cosmochim. Acta 53, 197-214.

Chung, S.L., Jahn, B.M., 1995. Plume-lithospheric interaction in generation of the Emeishan flood basalts at the Permian-Triassic boundary. Geology 23(10), 889-892.

Chung, S.L., Lan, C.-Y., Lo, C.H., Lee, T.Y., Wang, P.-L., Hoa, T.T., Thanh, H.H., Anh, T.T., 1998. The Indosinian orogeny and closure of eastern PaleoTethys: Amalgamation between the Indochina and South China blocks in the early Triassic. GEOSEA 98, 17-19.

Chung, S.L., Lee, T.Y., Lo, C.H., Wang, P.L., Chen, C.Y., Nguyen, T.Y., Tran, T.H., Wu, G.Y., 1997. Intraplate extension prior to continental extrusion along the Ailao Shan-Red River shear zone. Geology 25, 311-314.

Cung Thuong Chi, Dorobek, S.L., 2004. Cretaceous palaeomagnetism of Indochina and surrounding regions: Cenozoic tectonic implications. In: Malpas, J., Fletcher, C.J.N., Ali, J.R., Aitchison, J.C. (Eds.), Aspects of the Tectonic Evolution of China, 226. Geological Society Special Publication, 273-287.

Cung Thuong Chi, Geissman, J., 2013. A review of the paleomagnetic data from Cretaceous to lower Tertiary rocks from Vietnam, Indochina and South China, and their implications for Cenozoic tectonism in Vietnam and adjacent areas. Journal of Geodynamics, 69, 54-64.

Dovjikov, A.E. (Editor), 1965. Geology of Northern Viet Nam. General Dept. Geology of Viet Nam. Science and Technique Publishing, Hanoi, 668 (in Russian).

Flower, M.F.J., Russo, R.M., Tamaki, K., Hoang, N., 2001. Mantle contamination and the Izu-BoninMariana (IBM) 'high-tide mark': evidence for mantle extrusion caused by Tethyan closure. Tectonophysics, 333, 9-34.

Flower, M.F.J., Tamaki, K., Hoang, N., 1998. Mantle 
N. Hoang, et al./Vietnam Journal of Earth Sciences 38 (2016)

extrusion: a model for dispersed volcanism and DUPAL-like asthenosphere in East Asia and the WPAC. In: Flower, M.F.J., Chung, S.L., Lo, C.H. (Eds.), Mantle Dynamics and Plate Interactions in east Asia, Geodynamics Series, vol.27. American Geophysical Union, 67-88.

Gilder, S.A., Gill, J., Coe, R.S., Zhao, X.X., Liu, Z.W., Wang, G.X., Yuan, K.R., Liu, W.L., Kuang, G.D., $\mathrm{Wu}$, H.R., 1996. Isotopic and paleomagnetic constraints on the Mesozoic tectonic evolution of south China. Journal of Geophysical Research 101(16), 137-16, 154.

Hutchison, C., 1989. Geological Evolution of south-East Asia. Clarendon Press, Oxford, 368.

Ionov, D., Hofmann, A.W., 1995. Nb-Ta-rich mantle amphiboles and micas: Implications for subductionrelated metasomatic trace element fractionations. Earth Planet. Sci. Lett. 131, 341-356.

Ishizuka, O., Taylor, R.N., Milton, J.A., Nesbitt, R.W., 2003. Fluid-mantle interaction in an intra-oceanic arc: constraints from high-precision $\mathrm{Pb}$ isotopes. Earth and Planetary Science Letters 211, 221-236.

Jahn, B.M., Zhou, X.H., Li, J.L., 1990. Formation and tectonic evolution of southeastern China and Taiwan: isotopic and geochemical constraints. Tectonophysics 183, 145-160.

Lan, C-Y., Chung, S-L., Shen, J.J-S., Lo, C-H., Wang, P-L., Hoa, T.T., Thanh, H.H., Martzman, S.A., 2000. Geochemical and Sr-Nd isotopic characteristics of granitic rocks from northern Vietnam. Journal of Asian Earth Sciences 18, 267-280.

Le Bas, M.J., Le Maitre, R.W., Streckeisen, A., Zanettin, B., 1986. A chemical classification of volcanic rocks based on the total alkali-silica diagram. Journal of Petrology 27, 745-750.

Leloup, P.H., Lacassin, R., Tapponnier, P., Schärer, U., Zhong, D.L., Liu, X.H., Zhang, L.S., Ji, S.C., Phan Truong, T., 1995. The Ailao Shan-Red River shear zone (Yunnan, China), Tertiary transform boundary of Indochina. Tectonophysics 251, 3-84.

Ludwig, K.R., 2012. Isoplot, a geochronological toolkit for Microsoft Excel. Berkeley Geochronology Center, Special Publication, 5, 75.

Nguyen Dac Dong (Editor), 2000. Reports on 'geological mapping and mineral resource exploration of the Tram Tau sheet, 1:50,000 scale'. Archives of Geology, General Dept. Geology and Minerals of Viet Nam, Hanoi (in Vietnamese).

Nguyen Dinh Hop (Editor), 1997. Reports of geological mapping $(1: 50,000)$ of the north Tu Le - Van Ban sheet. Archives of Geology, General Dept. Geology and Minerals of Viet Nam, Hanoi (in Vietnamese).

Nguyen Hoang, Flower, M.F.J., Carlson, R.W., 1996. Major, trace element, and isotopic compositions of Vietnamese basalts: interaction of hydrous EM1-rich asthenosphere with thinned Eurasian lithosphere. Geochimica et Cosmochimica Acta 60, 4329-4351.

Nguyen Hoang, Flower, M.F.J., Cung Thuong Chi, Pham Tich Xuan, Hoang Van Quy, Tran Thanh Son, 2013. Collision-induced eruptions at Pleiku and Buon Me Thuot, south-central Viet Nam. Journal of Geodynamics 69, 65-83.

Nguyen Hoang, Itoh, J., Miyagi, I., 2011. Subduction components in Pleistocene to recent Kurile arc magmas in NE Hokkaido, Japan. Journal of Volcanology and Geothermal Research 200, 255-266.

Nguyen Hoang, Nguyen Dac Lu, Nguyen Van Can, 2004. Paleozoic volcanic rocks in the Song $\mathrm{Da}$ region: mantle sources and dynamics. J. Geology 282 (7-8, Series A), 10-18 (in Vietnamese with English abstract).

Nguyen Hoang, Uto, K., 2006. Upper mantle isotopic components beneath the Ryukyu arc system: evidence for 'back-arc' entrapment of Pacific MORB mantle. Earth and Planetary Science Letters 249, 229-240.

Nguyen Trung Chi, Bui Minh Tam, Phan Truong Thi, 1995. Geochemistry of the magmatism rocks from $\mathrm{Tu}$ Le zone, northwest Vietnam and their tectonic signification on Cenozoic evolution. Vietnam National University (Hanoi)-University Paris VI Workshop "Cenozoic Evolution of Indochina Peninsula" Abstracts, 75-76.

Nguyen Truong Giang, Nguyen Dac Dong, Nguyen Quang Hung, Tran Thanh Hai, Dang Tran Huyen, Pham Nguyen Phuong, 2003. New discoveries and characteristics of sediment - volcanic rocks in the Tram Tau area, Tu Le zone, Yen Bai province. Geology and Mineral Resources, 8, 93-104 (in 
Vietnam Journal of Earth Sciences 38(3), 242-255

Vietnamese with English abstract).

Nguyen Van Nhan, Hoang Minh Thao, 2002. Geochemical characteristics of $\mathrm{Pb}-\mathrm{Zn}$ mineralization in the Tu Le area. Journal of Geology, A(271), 7-8 (in Vietnamese with English abstract).

Nguyen Van The, 1999. Report on geology and mineral resources and accompanying geological map of 1:50,000 scale. Archives of Geology, General Dept. Geology and Minerals of Viet Nam, Hanoi.

Nguyen Vinh (Editor), 2005. Geology and Mineral Resources of the Yen Bai sheet (1:200,000 scale). Archives of Geology, General Dept. Geology and Minerals of Viet Nam, Hanoi.

Nguyen Xuan Tung, Tran Van Tri, 1992. Geological formations and geodynamics of Viet Nam. Science \& Technology Publisher, Hanoi.

Pham Duc Luong, Dang Tran Huyen, Nguyen Dinh Huu, Nguyen Duc Phong, Nguyen Thi Bich Thuy, 2010. Zircon U-Pb ages of volcanic rocks in the $\mathrm{Tu}$ Le Basin. Dia Chat (Journal of Geology), 320/910/2010 in Vietnamese with English abstract.

Phan Cu Tien (Editor), 1989. Geology of Campuchia, Laos and Viet Nam 1:1,000,000 scale. General Dept. Geology and Minerals of Viet Nam, Hanoi.

Phan $\mathrm{Cu}$ Tien (Editor), 1977. Explanations of geological maps of northwest Viet Nam: the Song Da sheet of 1:200,000. Science and Technology Publisher, Hanoi.

Royden, L.H., Burchfiel, B.C., van der Hilst, R.D., 2008. The Geological evolution of the Tibetan Plateau. Science 321(5892), 1054-1058.

Sun, S.-S., McDonough, W.F., 1995. The composition of the Earth. Chemical Geology 120, 223-253.

Tapponnier, P., Lacassin, R., Leloup, P.H., Schärer, U., Zhong, D.L., Wu, H.W., Liu, X.H., Ji, S.C., Zhang, L.S., Zhong, J.Y., 1990. The Ailao Shan/Red River metamorphic belt: Tertiary left-lateral shear between Indochina and South China. Nature 343, 431-437.

Tapponnier, P., Molnar, P., 1977. Active faulting and tectonics of China. Journal of Geophysical Research 82, 2905-2930.

Tapponnier, P., Peltzer, G., Armijo, R., Le Dain, A.Y., Cobbold, P., 1982. Propagating extrusion tectonics in Asia: New insights from simple experiments with plasticine. Geology 10, 611-616.
Tapponnier, P., Xu, Z.-Q., Roger, F., Meyer, B., Arnaud, N., Wittlinger, G., Yang, J.-S., 2001. Oblique stepwise rise of growth of the Tibet Plateau. Science 294, 1671-1677.

Taylor, S.R., McLennan, S.M., 1981. The composition and evolution of the continental crust: rare earth element evidence from sedimentary rocks. Philosophical Transactions of the Royal Society of London 301, 381-399.

Tran Duc Luong, Nguyen Xuan Bao, 1988. Geological map of Viet Nam, 1:500,000 scale. General Dept. Mines and Geology, Hanoi, Viet Nam.

Tran Trong Hoa, 1996. Mesozoic - Cenozoic magmatism in northwest Viet Nam and Truong Son: geochemical compositions, magma generation and mineral resource potential. Journal of Earth Sciences, 18, 2018-227.

Tran Trong Hoa, Izokh, A.E., Polyakov, G.V., Borisenko, A.S., Tran Tuan Anh, Balyakin, P.A., Ngo Thi Phuong, Rudnev, S.N., Vu Van Van, Bui An Nien, 2008. Permian - Triassic magmatic activity and mineral resources in northwest Viet Nam and the connection to Emeishan mantle plume. Journal of Geology and Geophysics, 49, 480-491 (in Russian).

Tran Tuan Anh, Tran Trong Hoa, Lan, C-Y., Chung, S-L, Lo, C-H., Wang, P-L., Mertzman, S. 2004. Mesozoic bimodal alkaline magmatism in Tu Le basin, North Vietnam: Constraints from geochemical and isotopic significances. J. Geology, Ha Noi, Series B(24), 1-9.

Tran Tuan Anh, Tran Trong Hoa, Pham Thi Dung, 2002. Granites in the Ye Yen Sun complex and their significances in tectonic interpretation of the early Cenozoic stage in West Bac Bo. Journal of Geology B(19-20), 43-53.

Tran Van Tri (Editor), 1977. Geology of Viet Nam, northern part. Science and Technology Publisher, Hanoi.

Tran Van Tri, Nguyen Xuan Tung, 1979. Geotectonic evolution of Northern Vietnam. XIV Pacific Sci. Congr. Com. B, sect. II, 48-49, Khabarovsk.

Tran Van Tri (Editor), 1979. Geology of Vietnam (North Part). General Department of Geology, Research Institute of Geology and Mineral Resources.

Tran Van Tri, Tran Trong Hoa, 2011. Late PaleozoicMesozoic Song Da - Tu Le intracontinental rift 
N. Hoang, et al./Vietnam Journal of Earth Sciences 38 (2016)

system. Geology and Natural Resources, Science and Technology Publisher, Hanoi, 425-431.

Vu Khuc, Bui Phu My, 1989. Geology of Viet Nam. Vol I. Stratigraphy). General Dept. Mines and Geology of Viet Nam, Hanoi, 378 (in Vietnamese)

Vu Khuc, Tran Trong Hoa, 2007. Current study status of the volcano-sedimentary Tu Le basin and remaining problems. Journal of Sciences of the Earth, 29(4), 296-300 9 (in Vietnamese).

White, W.M., Hofmann, A.W., Puchelt, H., 1987. Isotope geochemistry of Pacific mid-ocean ridge basalt. Journal of Geophysical Research 92(B6), 4881-4893.

Xu, J.-F., Castillo, P.R., 2004. Geochemical and Nd$\mathrm{Pb}$ isotopic characteristics of the Tethyan asthenosphere: implications for the origin of the Indian Ocean mantle domain. Tectonophysics 393, 9-27.

Xu, X.S., Griffin, W.L., O'Reilly, S.Y., Pearson, N.J., Geng, H.Y., Zheng, J.P., 2008. Re-Os isotopes of sulfides in mantle xenoliths from eastern China: progressive modification of lithospheric mantle. Lithos 102, 43-64.

Xu, Y.-G., Chung, S.L., Jahn, B.M., Wu, G.Y., 2001. Petrologic and geochemical constraints on the petrogenesis of Permian-Triassic Emeishan flood basalts in southwestern China. Lithos 58, 145-168.

Yang, Y., Liu, M., 2009. Crustal thickening and lateral extrusion during the Indo-Asian collision: A 3D viscous flow model. Tectonophysics 465, 128-135. 